\title{
SELF-DETERMINATION ABANDONED: THE ROAD TO THE NEW YORK AGREEMENT ON WEST NEW GUINEA (PAPUA), 1960-62
}

\section{David Webster}

"My Country favors a world of free and equal states ... Within the limits of our responsibility in such matters, my Country intends to be a participant and not merely an observer in this peaceful, expeditious movement of nations from the status of colonies to the partnership of equals. That continuing tide of selfdetermination, which runs so strong, has our sympathy and our support."

— John F. Kennedy to UN General Assembly, September 25, 1961

"We must meet our oft-stated pledge to the free peoples of West Berlin ... We have previously admitted our willingness to remove any actual irritants in West Berlin, but the freedom of the city is not negotiable. We cannot negotiate with those who say, 'What's mine is mine and what's yours is negotiable.' ... The solemn vow each of us gave to West Berlin in time of peace will not be broken in time of danger."

— John F. Kennedy's report to the nation on the Berlin crisis, July 25, 1961

"Oh, that is entirely different because there are something like two and a quarter million West Berliners where there are only seven hundred thousand of those Papuans. Moreover, the West Berliners are highly civilized and highly cultured, whereas those inhabitants of West New Guinea are living, as it were, in the Stone Age."

- John F. Kennedy in conversation with Netherlands Ambassador J. H. van Roijen, 1962 
In 1960, the Dutch colony of West New Guinea (WNG, later known as West Papua, West Irian, Irian Jaya, and Papua) embarked on a ten-year plan slated to end in selfdetermination for its indigenous Papuan population. This plan was presented explicitly within the framework of international decolonization and introduced during the time when the United Nations was working out its self-determination law, first enshrined in the UN declaration on the granting of independence to colonial countries and peoples (December 14, 1960). WNG was in many ways the first test case, and the international community failed this test abysmally. The reason was realpolitik, the strategic Cold War imperative driving the United States. The United States, while extolling self-determination as a high and holy principle for West Berlin and elsewhere, abandoned it for WNG. But it should be noted that the principle was also abandoned by the international community and all the players directly involved: Indonesia, Australia, and even the Netherlands. The sole exceptions were a group of African states whose representatives saw parallels to their own (then very recent) experience of political decolonization.

WNG was handed over to Indonesia in 1962 with the promise that an "act of free choice" would be put up to a public vote by 1969 . That this act was a stage-managed whitewash is generally accepted. ${ }^{1}$ But the principle of self-determination was, in fact, abandoned earlier, in the three-way Dutch-Indonesian-American negotiations of 1960-62. Self-determination was by no means impossible after this point, nor were Papuan rights to self-determination extinguished, but the path to self-determination was made much harder. After 1962, no major power would take the prospect for selfdetermination seriously in the Papuan case, and thus it was no surprise when the international community rubber-stamped the 1969 "act of free choice" and accepted WNG'S incorporation into Indonesia, an incorporation that is and was shaky under international law. This article traces the abandonment of the principle of selfdetermination leading up to the Dutch-Indonesian New York Agreement of August 1962, which put an end to Dutch rule in Papua and to the self-determination process. It does not attempt to address the full course of the dispute and its settlement. ${ }^{2}$

\footnotetext{
${ }^{1}$ John Saltford, "United Nations Involvement with the Act of Self-Determination in West Irian (Indonesian West New Guinea), 1968 to 1969," Indonesia 69 (April 2000): 71-92; Gabriel Defert, L 'Indonésie et la Nouvelle-Guinée Occidentale: Maintien des Frontières Coloniales ou Respect des Identités Commaunitaires (Paris: L'Harmattan, 1996); Carmel Budiardjo and Liem Soei Liong, West Papua: The Obliteration of a People, third edition (London: TAPOL, 1988); and Brian May, The Indonesian Tragedy (Singapore: Graham Brash, 1978).

${ }^{2}$ I have attempted to address the dispute more fully, from the viewpoint of the United States government, in David Webster, "Regimes in Motion: The Kennedy Administration and Indonesia's New Frontier, 19601962," Diplomatic History 33,1 (January 2009): 92-123. The most detailed source for the 1962 phase of the negotiations is Terence C. Markin, "The West Irian Dispute: How the Kennedy Administration Resolved that 'Other' Southeast Asian Conflict" (PhD dissertation, Johns Hopkins University Press, 1996). See also Christopher McMullen, Mediation of the West New Guinea Dispute, 1962: A Case Study (Washington, DC: Institute for the Study of Diplomacy, 1981); William Henderson, West New Guinea: The Dispute and Its Settlement (South Orange, NJ: Seton Hall University Press, 1973). A crucial study for this period is Bradley R. Simpson, Economists with Guns: Authoritarian Development and US-Indonesian Relations, 1960-1968 (Stanford, CA: Stanford University Press, 2008).
} 


\section{Self-determination Posed: Dutch Policy}

WNG had been part of the Dutch East Indies, and the Netherlands retained control when it accepted Indonesian independence in 1949. The Dutch government had claimed that it intended to remain in WNG to prepare the people for selfdetermination, but this was little more than empty rhetoric until 1960. First advanced in order to meet UN requirements (under Article 73[e]) for administration of a nonself-governing territory, and scrupulously repeated as mantra in Dutch reports to the $\mathrm{UN}$, this claim slowly took on the characteristics of an article of faith in Dutch policy and was stubbornly defended as a principle even while it was abandoned in practice. At no point were the Dutch willing to name a target date for Papuan independence, and they seem to have believed that rhetoric was enough, that the date could be extended indefinitely.

The tone of Dutch government attitudes through the 1950s can be summed up in a single example. On a visit to Washington, DC, foreign minister Joseph M. A. H. Luns explained that the natives of WNG were unswayed by Indonesian infiltrators, that they "either apprehended and reported these agitators to the local administration or they ate the agitators. He said there was only one variation to this latter practice and that existed among the more Christianized natives who would only eat fishermen on Fridays." ${ }^{3}$

The 1960 ten-year self-determination plan was advanced in order to craft a compromise among Dutch political parties, force Australia's hand in order to gain its military support, and forestall Indonesian moves. It was capped by the election of an advisory New Guinea Council in April 1960, with a Papuan majority headed by vicepresidents Nicolaas Jouwe and Markus Kaisiepo. However, as Indonesian pressure to occupy and govern Papua grew, the Dutch proved less and less willing to consult the Council. As the Council pronounced on international affairs and began to act like a de facto parliament, Dutch officials stressed repeatedly that the New Guinea Council and the new national symbols carried no weight in international law. ${ }^{4}$

In 1961, Luns advanced a plan that suggested the Netherlands was willing to give the UN authority over the future of WNG. This was the result of months of talks with American officials, but a Council delegation that visited the Netherlands a month before Luns introduced his plan was not informed of this new direction of Dutch thinking. On the Luns plan, Council member Eliezer Bonay said that if the Dutch pulled out, then WNG would have to declare independence. Dutch officials promised that if the Luns proposal failed, they would stand by their promise to ensure that Papua would be granted independence in ten years. Another Council member was assured that the government was "duty bound to carry out the promises which had been made ... the promise once made had to be fulfilled." Minister for WNG Theo Bot gave similar assurances during a tour of WNG in early $1962 .{ }^{5}$

\footnotetext{
${ }^{3}$ Record of meeting, Foreign Relations of the United States (henceforth FRUS), 1958-60, 17, p. 122.

${ }^{4}$ See, for instance, Department of State telegram to Secretary of State Dean Rusk in Bermuda, December 21, 1961, John F. Kennedy Library (henceforth JFKL), National Security Files (henceforth NSF), Box 205.

${ }^{5}$ Justus van der Kroef, "Toward “Papua Barat,'” Australian Quarterly 34,1 (March 1962): 20; Peter Savage,

"Irian Jaya: Reluctant Colony," in Politics in Melanesia (Suva: Institute of Pacific Studies, University of the
} 
Perhaps more important than actual Dutch beliefs was the American impression of what the Netherlands thought and could be brought to accept. Although the official government line from The Hague did not waver until well into 1962, American officials were receiving a quite different impression through back channels. Dutch journalist Willem Oltmans had been writing articles to muster support of Indonesia's claim to WNG for some time, and he briefed John F. Kennedy's national security staff in April 1961. His proposals were not accepted at the time but began to create the impression that, the words of their government notwithstanding, the Dutch people would accept American intervention on the side of Indonesia. Oltmans saw the dispute as one over "who will train the Papuans to eat with knife and fork." ${ }^{6}$ American officials always noted that the opposition Labour Party in the Netherlands was soft on the WNG issue. More importantly, they saw Dutch business as quite willing to hand over WNG, and the Dutch as unwilling to fight Indonesian forces in Papua to defend their claims. An administration dedicated to the masculinized ideas of dynamism, toughness, and "vigor" showed little respect for this stance. If the Dutch were not willing to fight, the thinking went, why should others pull their chestnuts from the fire? Consequently, as secretary of state Dean Rusk (the most pro-Dutch official in the administration) recalled, "I could not see the United States drafting boys off the farms of Kansas and the factories of Pittsburgh to do something in West Irian that the burghers of Amsterdam were unwilling to do for themselves." ${ }^{7}$

The impression that the Dutch would go along with a handover of WNG despite their claims was also confirmed by Dirk Stikker, Secretary-General of NATO and a former Dutch foreign minister who American officials believed spoke for the Dutch business community. Stikker in April 1961 gave a confidential briefing to former US secretary of state Dean Acheson (acting as Kennedy's envoy). Stikker reported that "Dutch politicians and people have now progressed to such an extent in their thinking that they would be extremely grateful if the US will take leadership in pushing through an international trusteeship arrangement for NNG [Netherlands New Guinea]." Finally, the views of the Queen's husband, Prince Bernhard, were that the Dutch would be willing to accept the handover of WNG, with foreign minister Luns the only person adamantly opposed. Bernhard expressed this view on several occasions through business back channels, through Acheson, and directly to Kennedy.

\section{Self-determination Scorned: Indonesian Policy}

Indonesian policy was to "regain" WNG, and to deny consistently that Papua had a separate right to self-determination. Self-determination, the argument went, had been exercised by the entire people of the Dutch East Indies, including WNG, on August 17, 1945, when Sukarno and Hatta declared the independence of Indonesia. "The people

South Pacific, 1982), p. 9; and Paul W. van der Veur, "Political Awakening in West New Guinea," Pacific Affairs 36,1 (1963): 54-73.

${ }^{6}$ Oltmans memo and discussion, TFKL, NSF, Box 113; Oltmans memo to Rostow, April 1961, IFKL, President's Office Files (henceforth POF), Box 122a.

${ }^{7}$ Dean Rusk oral history, JFKL.

${ }^{8}$ US embassy The Hague to Department of State (henceforth DOS), April 10, 1961, JFKL, POF, Box 122a; Henry G. Walter memo to DOS, May 3, 1961, JFKL, NSF Box 205. 
whom the Netherlands call Papuans are our brothers and sisters from Irian," as one Indonesian ambassador told the UN. "We all belong to the same nation: the Indonesian nation. ${ }^{\prime 9}$ Indonesian vice president Mohammad Hatta and a minority of Indonesian nationalists had actually been willing to omit Papua from their new independent state, although, judging from the records, there seems to be some confusion as to what they meant by Papua: some thought WNG, while some apparently meant the Australianruled Territory of Papua and new Guinea. ${ }^{10}$ The confusion illustrates how the Indonesian nationalist imagination lacked a full awareness of the territory and considered it little more than a Dutch prison camp for dissidents.

Some Papuans initially supported Indonesia. This group, led by Silas Papare, mostly left WNG for Indonesia and formed the Gerakan Rakyat Irian Barat (GRIB, West Irian People's Movement). In 1956, Papare declared an autonomous Indonesian province of West Irian, but Indonesia refused to acknowledge it, instead setting up its own paper province. ${ }^{11}$ Since this province was headed by the Sultan of Tidore, best known for his dynasty's slave trade of Papuans, it was unlikely to attract much Papuan support. It was most important, however, as a sign that the Indonesian government intended to claim the territory of WNG without reference even to Papuans who called for incorporation of the territory into Indonesia.

The GRIB Papuans cannot be dismissed as simply "pro-Indonesian." It could be argued that they were, in a sense, exercising self-determination in making a choice for a self-governing WNG federated with Indonesia. After the New Guinea Council was in place, and especially after the Papuan flag was raised on December 1, 1961, some of them may have joined the call for an independent West Papua. Papare told the American ambassador in December 1961 that he planned to return home and assist in composing an independence declaration, and he requested United States support for the new nation. A little under a year later, Papare was reported to have been arrested and jailed in Jakarta on suspicion of opposing Indonesian government policies. ${ }^{12}$

On December 19, 1961, Sukarno issued the "three-fold command of the people" (Trikora), specifically designed to thwart Papuan self-determination before it was too late. Shortly thereafter, he wrote to Kennedy: "I hope to have your understanding that as long as the Netherlands continue with their preparations for the proclamation of Independent Papua (the so-called Papua flag and national anthem have already been introduced into West Irian), there is no alternative left to us but the use of force in order to face this illegal, forceful occupation of West Irian by the Netherlands." ${ }^{13}$

\footnotetext{
${ }^{9}$ Wiryopranoto, speech to General Assembly, November 8, 1961, UN document A/ PV.1049, p. 599.

${ }^{10}$ Ibid.; Background to Indonesia's Policy towards Malaysia: The Territory of the Indonesian State, Discussions of the Badan Penjelidik Usaha Persiapkan Kemerdekaan Indonesia (Jakarta: Department of Information, 1964).

${ }^{11}$ Jaren van Reconstructie: Nieuw-Guinea van 1949 tot 1961 ('s-Hertegenbosch: n.p., 1962), p. 210, at http:/ / cornell.worldcat.org / title/ jaren-van-reconstructie-nieuw-guinea-van-1949-tot-1961-a-reshapingprocess-in-new-guinea-1949-1961-with-a-summary-in-english/oclc/9657924\&referer=brief_results; and Autonomous Province of West Irian (Jakarta: Department of Information, 1956).

${ }^{12}$ US Embassy in Jakarta to DOS, December 15, 1961, JFKL, NSF, Box 205; Committee Self-Determination New Guinee to U Thant, November 20, 1962, United Nations Archives (henceforth UNA), S-0279-00250004 .

${ }^{13}$ Sukarno to Kennedy, December 16, 1961, JFKL, NSF, Box 113.
} 


\section{Self-determination Ignored: US Policy}

From the beginning of the Kennedy administration's reconsideration of the WNG problem, the question of self-determination appears to have had virtually no impact on the thinking of American government officials. It was simply not on the agenda, except as an idea to dismiss.

The United States shocked Dutch and Papuan leaders when it decided to boycott the installation of the newly elected New Guinea Council in April 1961. This decision reversed one made a few days earlier, when the United States had declared its intention to send representatives to the Council, and was made personally by JFK as a result of the grave international situation: a verbal commitment to send American troops to Laos. Given this plan to intervene in Laos, the United States did not wish to take the chance of further inflaming the situation in Southeast Asia. As a State Department position paper for Kennedy noted, "we were seriously concerned with the Laos situation at that time and desired to prevent a political explosion in this sensitive area ... in view of our larger responsibilities in Asia, it was a decision that we considered must be made." ${ }^{14}$

The decision to boycott the April ceremonies also managed to curry favor with Sukarno's government just days before the Indonesian president arrived in Washington for a state visit. As one national security staffer wrote: "The US reversal of its stand on attendance at the Dutch New Guinea ceremonies has had a very favorable impact upon the Indonesians. This action and our UN action on Angola seem to have had a considerable effect in convincing the Indonesians that the new Administration takes a different view of colonial questions." ${ }^{15}$

No key American officials seem to have held any belief in self-determination, believing the Papuans were not likely to be ready for self-government any time soon. This attitude was reinforced by a distinct racism in the inner circles of the civil rights administration. Robert Komer, the responsible official on Kennedy's national security staff for Asia and Africa, called for "cold realpolitik," which meant being willing to sacrifice "a few thousand square miles of cannibal land." Fellow national security staffer Robert Johnson regretted that, "We never indicated to the Dutch officially that we considered self-determination [a] meaningless facade when applied to stone-age people almost totally lacking in contact with the modern world." Robert Amory of the CIA called a plebiscite "farcical ... considering the stone-age level of the West New Guineans." 16

The "official mind" of the Kennedy administration, in other words, had space for the principle of self-determination, but none for the application of that principle to WNG, which the officials perceived as a mere "bit of colonial debris" complicating Southeast Asian strategy. Popular images did little to change that: the vast WNG

\footnotetext{
${ }^{14}$ Memo of conversation, March 27, 1962, JFKL, POF, Box 122a, file 3; Robert Komer to McGeorge Bundy, March 24, 1961, JFKL, NSF, Box 423; US position paper on Luns visit, A pril 10-11, 1961, JFKL, POF, Box 122a.

${ }^{15}$ Memo of conversation, April 17, 1961, JFKL, NSF, Box 113

${ }^{16}$ Robert Komer memo, "Why Trusteeship Won't Work," February 17, 1961, JFKL, NSF, Box 205; Komer to Bundy, February 16, 1962, JFKL, NSF, Box 206; memo to President, November 30, 1961, FRUS 1961-63, 13, p. 467; and memo by Robert Amory, February 20, 1961, JFKL, NSF, Box 206.
} 
region was represented dimly through images of half-naked Dani tribesmen transmitted by Harvard anthropologists, and known as the place where New York Governor Nelson Rockefeller's anthropologist son Michael drowned in 1961.

\section{Self-determination Outvoted: The UN General Assembly, 1961}

Dutch foreign minister Luns took a plan for self-determination to the UN in the fall of 1961. "What is important now, and of paramount importance, is the future of Netherlands New Guinea," he declared. "On that future, no one except the Papuans themselves is entitled to decide." ${ }^{17}$ Nevertheless, the Luns plan was based almost entirely on discussions not with Papuans but with United States officials. The debate on WNG took place in the context of the broader UN debate on implementation of the declaration on the granting of independence to colonial countries and peoples. A thirty-eight-country resolution from Third World states was passed calling for the granting of independence to all countries not yet independent, and creating the Special Committee on Decolonization. With Indonesia as one of the lead sponsors, the resolution also expressed concern that territorial integrity of some states was being disrupted by decolonization processes (the implicit reference here was to Indonesia's claim to WNG, Iraq's to Kuwait, and similar cases).

WNG was the only country to be considered specifically in the debate on the declaration when participants turned to discuss the granting of independence to colonial countries and peoples. After some negative reactions, the Luns plan was withdrawn in favor of one advanced by the Brazzaville group of African states, most of them having recently achieved independence from France. The Dutch and then the Brazzaville group presented their plans as attempts to realize the general intent of the declaration in a specific case where decolonization had not yet been implemented. The thirteen-country Brazzaville group resolution (sponsored by Cameroun, Central African Republic, Chad, Congo-Brazzaville, Dahomey, Gabon, Ivory Coast, Madagascar, Mauritania, Niger, Senegal, Togo, and Upper Volta) called for negotiations on WNG and also for a UN Commission on WNG, which would make recommendations as to self-determination if negotiations did not succeed within one year. In speeches, the Brazzaville countries highlighted the rights of the people of WNG as their central concern.

Although Western countries backed this resolution, Indonesia objected to its stress on self-determination, arguing that self-determination had already been exercised for all of Indonesia in 1945 and that WNG could not be "amputated" from Indonesia. Indonesia also demanded support from other Third World countries and was able to call in debts from many in Asia and Africa. In many cases (particularly in Africa), the delegates originally favored the self-determination plans, but Indonesian pressure (in at least one case including a threat to break diplomatic relations) forced a vote against. ${ }^{18}$ The resolution received 53 votes in favor, to 41 against, with 9 abstentions, falling short of the two-thirds majority needed for passage. Essentially, the votes were

\footnotetext{
${ }^{17}$ Luns speech to General Assembly, November 8, 1961, UN document A/PV.1049, p. 589.

${ }^{1 s}$ Adlai Stevenson, US ambassador to UN, to DOS, September 27, 1961, JFKL, NSF, Box 205; US embassy Rio de Janeiro to DOS, September 27, 1961, JFKL, NSF, Box 205.
} 
distributed according to region. In favor were the Brazzaville African countries, most of Latin America, Western Europe, and North America. Opposed were the Casablanca group of African countries, most of Asia, and the Soviet bloc.

The Brazzaville initiative is generally downplayed or ignored in accounts of the WNG dispute. It should not be. For this group, the decolonization of WNG was perceived as part of an international wave of decolonization that had liberated a number of African states. The geographical distance separating Africa from Papua was considered immaterial. This is a theme that Papuan diplomats sought to play upon in their search for African support. Nor was this feeling confined to those more moderate African states: Tanzania launched a brief effort, its first initiative outside Africa, to promote a peaceful settlement of the WNG dispute that would protect Papuan selfdetermination.

Although the United States' mission to the UN suggested the Brazzaville states be congratulated for their constructive efforts, the White House ignored that idea and shifted towards taking over control of the WNG file, a responsibility previously left to the State Department. "At that point," recalled Dutch Ambassador to the United States, J. H. van Roijen, members of the Kennedy administration "decided they could no longer stand behind us." ${ }^{19}$ The first American move to resolve the WNG dispute through the UN had backfired. Now Kennedy's national security staff began to recommend a tougher line. "[W]ith the failure of our UN gambit," Komer recommended, "the time has come to take the gloves off, and adopt a frankly proIndonesian stance while there's still time to get some political capital out of it." ${ }^{20}$

\section{Self-determination Abandoned: The 1962 Negotiations and Huntlands Agreement}

January 1962 marked a turning point. At this time, the US president's office decided that the United States would have to get involved to resolve the issue, and from the beginning Kennedy's staff felt that any solution would have to be on Indonesian terms. The State Department was not so convinced, but the consistent White House policy to favor Indonesia has to be noted as background to all US policy twists and public statements from this point onwards. American officials had professed to the Dutch that the United States would support self-determination for the Papuans, but ceased to mention it in talks with the Indonesians.

The Netherlands made its own policy shift in January 1962. Prime Minister J. E. de Quay offered to talk to the Indonesians and drop his government's precondition that self-determination be endorsed, asking, in return, that Indonesia abandon its precondition that the purpose of the talks would be to transfer WNG to Indonesia. Indonesian foreign minister Subandrio counter-proposed that "Sukarno would make a statement on self-determination in return for Dutch agreement [that the] purpose [of] talks [was to] transfer administration [of WNG] to Indonesia." This deal, if accepted, would have offered Papuans a better deal than they eventually received. Luns, in fact, told the United States that the "Netherlands Government will not agree to turn over

\footnotetext{
${ }^{19}$ van Roijen oral history, JFKL.

${ }^{20}$ Memo to Rostow, November 30, 1961, FRUS 1961-63, 13, pp. 469-70.
} 
administration to Indo[nesia] no matter what guarantees there are for eventual exercise [of] self-determination by Papuans." ${ }^{21}$ Dutch diplomatic prestige, in other words, outweighed Dutch promises that Papuans would be ensured of self-determination.

After Robert Kennedy visited Jakarta and The Hague in February to urge talks, eight New Guinea Council members wired John F. Kennedy:

We protest strongly Robert Kennedy's humiliating statements on television concerning backwardness Papuan people and lack university trained workers, seemingly indicating advise [sic] to Indonesia to eradicate Papuan people ... Independence and democracy can be understood and practiced by common people even if they have not seen Harvard and we have an unalienable right to such practicing and we ask technical aid for it from the more advanced people of the world. Robert Kennedy should be ashamed if he tries to play poker with the fate of backward people for no other reason than to appease a dictator. ${ }^{22}$

This telegram was not answered. "In the opinion of the Department, there is no advantage to be gained by replying to these persons," the State Department advised the president. ${ }^{23}$

In March, Luns visited Washington, DC. According to the official record of his meeting with John Kennedy, "the president emphasized that by concentrating too much on the future of the Papuan population we may be forgetting our other obligations in Asia and free Europe." In this meeting, Luns abandoned his earlier commitments to include Papuans in the Dutch delegation to any negotiations with Indonesia. ${ }^{24}$

American pressure finally forced both sides to agree to negotiations that opened in March 1962 at the Huntlands estate near Washington, DC. Mediator Ellsworth Bunker was ostensibly acting for UN Secretary General U Thant, but in fact acted as a representative of the United States government. ${ }^{25}$ Talks opened with the Dutch insisting that WNG must be granted self-determination, that this was their bottom line, and the United States calling self-determination a high principle. In the course of talks, the principle was abandoned by all negotiators and replaced with a face-saving promise that an "act of free choice" would be proposed and representatives of Papua be given the opportunity to vote on the measure in 1969; this promise was written into the final agreement.

Van Roijen told Bunker that he believed WNG would eventually go to Indonesia because "there is no other place for it to go." He said Papuans must have "a fair

\footnotetext{
${ }^{21}$ Arend Lijphart, The Trauma of Decolonization: The Dutch and West New Guinea (New Haven, CT: Yale University Press, 1966), p. 277; DOS to US embassy Jakarta, January 16, 1962, JFKL, NSF, Box 205; US embassy The Hague to DOS, February 3, 1962, JFKL, NSF, Box 205.

${ }^{22}$ Papuan telegram and covering note from L. D. Battle to Bundy, March 8, 1962, JFKL, NSF, Box 206.

${ }^{23}$ Ibid.

${ }^{24}$ Memo of conversation, March 2, 1962, FRUS 1961-63, 13, p. 549; Markin, “The West Irian Dispute," pp. 115-18.

${ }^{25}$ McMullen, Mediation.
} 
referendum, plebiscite, or other mode of self-determination." Consequently, Bunker's formulas begin to refer to an act of self-determination in very vague terms. ${ }^{20}$

Bunker put forth a formula that formed the basis of the eventual deal: the Netherlands would hand WNG over to the UN, which would administer the territory for a short interim period and then hand it to Indonesia, with the final step being an act of self-determination organized by the Indonesian government and the UN together. This precisely duplicated an earlier suggestion from Indonesian foreign minister Subandrio that his country might be willing to "borrow the hand of the United Nations" in order to ease transfer of control. Yet this plan was no longer enough for an increasingly assertive regime in Jakarta. Indonesian delegates broke off talks, prompting Bunker to add to his formula the idea that transfer must come before selfdetermination. The suggestion, which seemed to represent US government policy also, brought talks back on course. Van Roijen said this would be regarded as "abject surrender." Putting the transfer clearly first meant, in the words of a source close to Bunker, "the plebiscite would be essentially a face-saving device for the Dutch rather than a meaningful expression of free choice." Van Roijen professed shock that the plan seemed to put Western interests ahead of the Papuans'; Bunker "agreed bluntly his thinking was in fact in those terms." ${ }^{27}$

The Bunker plan was backed over the next months by the full weight of American, British, and Australian diplomacy. In a confidential discussion at NATO headquarters, Stikker noted that Luns had reported Papuans now held 60 percent of administrative positions. "If this is so, Stikker suggested, then Papouans [sic] themselves could be given responsibility of negotiating directly with Indonesians. Stikker thought that Papouans should be permitted to act without Dutch participation, since in the latter case they would be 'swamped' by Dutch." ${ }^{28}$ There was no apparent attempt to act on this suggestion.

In other words, Papuans were sidelined completely in the negotiations process, which seems to indicate the Dutch prized self-determination as a high principle but had little real interest in seeing it exercised. There is little indication that they fought very hard to have Papuans included in the talks, only that they jealously guarded their prerogatives as an administering power. The United States was only too happy to go along. In the words of US Assistant Secretary of State for the Far East Averell Harriman: "We were trying to save the Dutch from themselves." ${ }^{29}$

Enormous pressure was exerted in this quest. John Kennedy wrote to de Quay on April 2, 1962, to call for talks to resume lest a war break out.

This would be a war in which neither The Netherlands nor the West could win in any real sense. Whatever the outcome of particular military encounters, the entire

\footnotetext{
${ }^{26}$ McGhee to Jones, March 23, 1962, JFKL, NSF, Box 206; Markin, “The West Irian Dispute,” p. 163, italics in original.

${ }^{27}$ McMullen, Mediation, pp. 28-31; March 27, 1962, conversation with Bunker, cited in Markin, "The West Irian Dispute," p. 180; and van Roijen oral history, JFKL.

${ }^{2 s}$ Stuart Doran, “Western Friends and Eastern Neighbours: West New Guinea and Australian SelfPerception in Relation to the United States, Britain, and Southeast Asia, 1950-1962" (PhD Dissertation, Australian National University, 1999); US embassy Paris to DOS, May 22, 1962, JFKL, NSF, Box 206.

${ }^{29}$ Harriman oral history, JFKL.
} 
free world position in Asia would be seriously damaged. Only the communists would benefit from such a conflict. If the Indonesian Army were committed to an all-out war against The Netherlands, the moderate elements within the army and the country would be quickly eliminated leaving a clear field for communist intervention. If Indonesia were to succumb to communism in these circumstances the whole non-communist position in Viet-Nam, Thailand, and Malaya would be in grave peril and as you know these are areas in which we in the United States have heavy commitments. ${ }^{3 \prime \prime}$

Bunker assured van Roijen that the United States government "expected" a free and fair exercise of self-determination for the Papuans. But Bunker's true views came through in an off-the-record press briefing: "The country itself is not viable. The inhabitants are largely backward, living, I am told, most of them in the Stone Age, except along the coastal areas, fringes along the coast ... I think you would understand that, certainly in my opinion, a very small part of the population today is capable of exercising self-determination, or any determination of anything for that matter." ${ }^{31}$

At the same time, the United States sought and obtained from the Netherlands assurances that there were no plans to declare an independent Papuan state on April 5 to mark the first anniversary of the New Guinea Council. "Essential you obtain from Netherlands Government assurances which we can pass on to Indonesians that Papuan independence will not be announced," Rusk instructed his ambassador in The Hague. The United States even tried to prevent a visit to WNG by the UN ambassadors of Dahomey and Upper Volta. The Dutch offered promises that they would not authorize an independence declaration, and that if one were made they would oppose it. $^{32}$

International pressure brought both sides back to Huntlands in July. By the end of talks, Indonesian delegate Adam Malik had agreed to all but one of Bunker's draft points of agreement-the point on self-determination. Bunker's next list of twenty points, seen as a framework for a final agreement, avoided use of the term "Papuans" in favor of "inhabitants of the territory." "33

A UN official, Constantine Stavropoulos, was asked to prepare an outline of how the act of free choice might be carried out. A cover note from Stavropoulos indicated his sympathy for Papuan claims: “... at least since President Wilson enunciated the principle of self-determination in 1918, there appears to emerge a strong presumption in favour of self-determination in situations such as that of Western New Guinea on the basis of the wishes of the people of the territory concerned, irrespective of the legal stands or interests of other parties to the question." Bunker initially welcomed the plan, but backtracked when Malik objected. ${ }^{34}$ The proposal was then jettisoned in favor of a single article that appeared in the final agreement. The differences between

\footnotetext{
${ }^{30}$ Kennedy letter to de Quay, April 2, 1962, JFKL, POF, Box 122a.

${ }^{31}$ McMullen, Mediation, p. 38; Bunker press briefing, June 1, 1962, JFKL, NSF, Box 423.

${ }^{32}$ DOS to US embassy The Hague, March 31, 1962, and US embassy The Hague to DOS, April 1, 1962, JFKL, NSF, Box 206.

${ }^{33}$ US embassy The Hague to DOS, April 1, 1962, JFKL, NSF, Box 206.

${ }^{34}$ Cover note of Stavropoulos study, June 29, 1962, and Stavropoulos Plan, UNA, S-0884-0023-03;

Stavropoulos to U Thant, July 18, 1962, UNA, S-0884-22-6.
} 
Stavropoulos's proposal and this agreement were significant. Under the Stavropoulos plan, a UN commissioner would be continuously present in WNG until the "act of free choice" was put up for a vote, and that commissioner would both "participate and assist" in consultations with the population on the method of the act, its timing and conditions, the formulation of questions, and establishing categories of eligible voters on the basis of universal adult suffrage. In the final Huntlands agreement, however, UN staff duties were limited to "advising on, and assisting in, preparations for carrying out the provisions for self-determination except as Indonesia and the Secretary-General may agree upon their performing other functions." Staff would remain as needed, but a UN commissioner would be appointed only one year before the act. Indonesia was to make arrangements to consult the population concerning the best means of determining the popular will. ${ }^{35}$

Even autonomy was abandoned without comment during talks. Indonesia had been promising some form of autonomy to Papua for years. As late as January 1962, Subandrio told the US ambassador that "Indonesians would leave Papuans in charge in West New Guinea, that there would be no attempt to put Javanese or Ambonese administrators in the territory." Now, these promises were discarded. "When West Irian becomes a part of Indonesia it will be governed centrally from Jakarta," said one Indonesian negotiator, adding "we do not want a legally separate apparatus in West Irian. Psychologically that is unacceptable." ${ }^{36}$

The terms of the final Huntlands agreement were similar to those Subandrio had floated in the UN, terms previously rejected by the Netherlands representative as "a mockery of the principle of free choice." When the deal was concluded, most observers felt the same. "No one regarded the stipulations for 'free choice' by the Papuans as more than a formality," according to the annual international affairs survey published by the Council on Foreign Relations. ${ }^{37}$

A UN resolution endorsing the deal passed 89 to zero, but with 14 abstentions. The abstentions came from twelve African states (Cameroon, Central African Republic, Chad, Dahomey, Gabon, Ivory Coast, Madagascar, Mauritania, Niger, Rwanda, Togo, and Upper Volta), plus France and Haiti. Objections on the grounds of selfdetermination were voiced by Dahomey, Upper Volta, and Togo. ${ }^{38}$

\section{The Act of No Self-determination}

The day after the agreement was signed in New York, Kennedy sent a letter to Queen Juliana of the Netherlands. "We know how deeply your Government has been concerned to reach an honorable future for the Papuan people, and I want to assure

\footnotetext{
${ }^{35}$ Agreement between the Republic of Indonesia and the Kingdom of the Netherlands Concerning West New Guinea (West Irian), articles 16-18.

${ }^{36}$ US embassy Jakarta to DOS, January 8, 1962, JFKL, NSF Box 205; Zain, in Huydecoper's notes, cited in Markin, "The West Irian Dispute," pp. 365-66.

${ }^{37}$ Dutch ambassador Schuurman, General Assembly speech, November 15, 1961, UN document A/PV.1055, p. 665; Richard Stebbins, The United States in World Affairs 1962 (New York, NY: Harper \& Brothers, 1963), p. 209.

${ }^{38}$ General Assembly Official Records, A/PV.1127, A/PV.1150.
} 
you of the continuing concern of the United States for this same objective," he wrote. ${ }^{39}$ But any American inclination to monitor the agreement soon vanished as the Netherlands seemed disinclined to pay much attention to seeing that a plebiscite was actually held. In May 1963, for example, the State Department reported to Kennedy in advance of a meeting with Luns that the Dutch were reportedly willing to drop the plebiscite idea. ${ }^{40}$

Indonesia never accepted that there was any obligation to hold a plebiscite under international law, since the Huntlands agreement was merely a bilateral pact between Indonesia and the Netherlands (this is why the UN General Assembly was only asked to "take note" of the agreement and not to endorse it). Still more seriously, Indonesia explicitly denied that the Papuans had a right to self-determination. Papuans would be given the opportunity to vote on the act of free choice, the Suharto government announced, only in order to show that Indonesia honored its treaties. ${ }^{41}$ Given the power of this Jakarta-centric viewpoint, it is hardly surprising that there was no valid self-determination in 1969. Indonesian policymakers accepted that they had to display the forms of determining the people's opinion, but never accepted any obligation actually to determine the people's opinion.

There was little concern with self-determination when the UN gave its seal of approval to the integration of Papua into Indonesia in 1969. Lingering efforts were made by a number of African states to see the reality of self-determination exercised, however. Ghana called for a new act of free choice, which would be submitted to the people by 1975. This plan was rejected 60 to 15 (those in favor: Gabon, Ghana, Guyana, Israel, Jamaica, Kenya, Sierra Leone, Togo, Trinidad and Tobago, Uganda, Tanzania, Barbados, Central African Republic, and Dahomey) with 39 abstentions. The final vote approved the act by 84 to zero, but symbolic abstentions in support of the principle of self-determination were made by thirty countries. Senegal voted in favor, but then announced it had meant to vote against. ${ }^{42}$ Only in the past decade is the international legality of the whole arrangement being reconsidered and questioned. ${ }^{43}$

\section{The Need for Historical Dialogue}

Indonesian and Papuan nationalists deploy very different versions of this history. The two clashing historical narratives are not simply different ways of representing the past. The different perceptions of the past are a root cause that helps to constitute the

\footnotetext{
${ }^{39}$ Kennedy to Queen Juliana, August 16, 1962, JFKL, POF, Box 122a.

${ }^{40}$ Memorandum from Bruebeck to Bundy, May 24, 1963, JFKL, POF, Box 122a.

${ }^{41}$ Speech of Foreign Minister Adam Malik to the UN, General Assembly Official Records, meeting of November 13, 1969, A / PV.1810; Indonesia's report on the act of free choice, Annex B to UN document A/7723; and Summary of actions taken to date by UN to implement its part in New York Agreement, [1967 Secretariat note], UNA, S-0884-23-10.

${ }^{42}$ General Assembly Official Records, November 13 and November 19, 1962, UN documents A/PV.1810, A/PV.1812, and A/PV.1813.

${ }^{43}$ Powes Parkop, "Reinscription of West Papua as a Colonised State and People," http: / / www.freewestpapua.org/docs/ parkop.htm, accessed January 24, 2013; Jason MacLeod and Brian Martin, "The legal strategy for West Papua: Will it Fly? What Might Help It To?" University of Sydney Centre for Peace and Conflict Studies, 2012, http: / / sydney.edu.au/arts/ peace_conflict/docs/ working_papers/WPP\%203.pdf, accessed Tanuary 29, 2013.
} 
current conflict. Historical dialogue is needed if there is to be any prospect of resolving the conflict, since the perception of "sovereignty-denied" is itself a root cause of Papuan nationalist feeling and aspirations.

The Indonesian nationalist narrative about Papua is a story of dispossession, Dutch colonialism, and Indonesia's ultimate victory in its anticolonial struggle. According to this narrative, the campaign to complete the decolonization of the whole East Indies served as a mobilizing focus to unite the new Indonesian state. The use of history to build unity peaked under Suharto. Centralizing nationalist historiographies left little space for local tellings: "The history classroom functioned to suppress knowledge of difference," as Jean Taylor has written. The key problem, in the words of historian Asvi Warman Adam, is that "Indonesian history was written uniformly by men in uniform." ${ }^{44}$ So the 1969 "act of free choice" was less referendum-a word never usedthan a display of respect for legal norms, designed for international consumption. The "West Irian struggle," a piece of Indonesian-nationalist historiography, erased the people from their own story. ${ }^{45}$

The Papuan nationalist version of history, by contrast, argues that justice has been denied, and this confers a moral right to self-determination. It holds that the right of self-determination can only be exercised by the Papuan people. According to many who share this perspective, self-determination was actually exercised in 1961 when the Papuan flag flew for the first time, and Papua has been "already sovereign" ever since. ${ }^{46}$ One claim of self-determination put forward at a mass meeting in Biak in 1962 will serve to illustrate many. According to the UN declaration on decolonization, the meeting resolved that: "the rights of small nations are the same as those of the big nations. Thus the rights of the Papuans are the same as those of the Americans, and the rights of the Papuans are the same as those of the Burmese." But the United States had "sold the rights of the independence of the Papuan population to Indonesia through the Bunker proposal, in order to be forever colonised by Indonesia." Thus, the meeting rejected the Bunker plan, which "means the surrender of our country and population to Indonesia." 47

The theme of self-determination denied persists, and continues to lie close to the root of conflict. The Papuan historical narrative has emerged in the gaps in the official Indonesian version of the region's history. Because Papua can make historical claims to independence based on the 1949-62 period, its nationalist movement regularly demands a setting-straight of the historical record (pelurusan sejarah). Only through this

\footnotetext{
${ }^{44}$ Jean Gelman Taylor, Indonesia: Peoples and Histories (New Haven, CT: Yale University Press, 2003), p. 362; Adam cited in Armando Siahaan, "Setting History Straight," Jakarta Globe, A pril 30, 2009, http: / / lists.topica.com/ lists/indonesia-act@igc.topica.com/ read/message.html?sort=d\&mid=813476589, accessed January 29, 2013.

${ }^{45}$ See, for instance, Sejarah Nasional, jilid 3 untuk SMA [National History for Upper-Level High Schools] (Jakarta: Departemen Pendidikan dan Kebudayaan, 1981), pp. 157-61.

46 "Bangsa Papua telah berdaulat sebagai sebuah bangsa dan negara sejak 1 Desember 1961," Second Papuan Congress resolution, June 4, 2000. The official English version adopts the name "West Papua" for international consumption: "The People of West Papua has been Independent as a Sovereign Nation and State since 1 December 1961." See http:/ / dujanwendanak.wordpress.com/2012/01/13/ kongres-rakyatpapua-ii-resolusi/ and an and an english translation at http:/ / www.freewestpapua.org/docs/ congressII.htm both accessed Feb. 10, 2013.

${ }^{47}$ Resolution of Biak-Nunfoor mass meeting, August 10, 1962, UNA S-0884-0023-0001.
} 
"straightening" can the "memory of suffering" (memoria passionis) be satisfied and peace be made possible. ${ }^{48}$

Historical narratives are not just classroom stories. They can be used to justify acts of violence. Indonesian security forces continue to tag any Papuan dissident as a "separatist" and to treat that label as sufficient justification to adopt repressive tactics. A 2005 protest in Papua demanded the end to state violence committed against people "simply because their understanding of history differs from that of the government." 49

The democratic governments that emerged in Indonesia after the fall of President Suharto in 1998 offered special autonomy for Papua, a move with potential to resolve the conflict. In avoiding the symbolic aspects of the struggle and refusing to engage in a dialogue that addressed historical narratives, however, Indonesia's central government failed to do so. Jakarta granted a greater share of the region's natural resource revenues and political autonomy to the Papuans, but rejected their symbolic claims and thus ignored the emotive force behind calls for independence. The issue was still framed in terms of uneven economic development, so the solution remained development-oriented. The Papuan call for historical dialogue became, in the final autonomy package passed in Jakarta, a commission empowered to "provide clarification of Papua's history in order to strengthen the people's unity in the State of the Republic of Indonesia." 50

In the dialogue that achieved a peace deal in Aceh, both sides agreed to lay aside their historical grievances and start fresh. Such an approach is less viable in Papua, where the perception of historical betrayal fuels nationalist sentiment. An acknowledgement of the Papuans' historical grievances will have to be included in any dialogue, as a key starting point, or else dialogue will ignore a key cause of conflict. This point was accepted in a recent "Papua Road map" from the Indonesian Institute of Sciences (LIPI, Lembaga Ilmu Pengetahuan Indonesia), but not as yet by the Indonesian government. A coordinating author of the "road map," Muridan Widodo, wrote recently: "History should not be treated as a fixed position involving absolute truth and determining collective identity. Rather, history should be treated as a negotiable construction involving acceptance and compromise, and providing benefits for both parties rather than being the monopoly of just one side. Otherwise, history in Papua will perpetuate an endless cycle of violence." ${ }^{51}$ Any prospect of lasting peace will need to include an honest reexamination of the period in which self-determination

\footnotetext{
${ }^{48}$ Memoria Passionis is the title of an annual series of human rights reports from the Catholic diocese of Jayapura, accessible from http: / / www.hampapua.org/skp/index2.html, accessed January 24, 2013.

49 "The Six Demands of the Dewan Adat Papua, August 12, 2005," accessed February 10, 2013, from http:/ / lists.topica.com/lists / WestPapua/ read/message.html?sort=a\&mid=1719298284

${ }^{50}$ Sekretariat Keadilan dan Perdamaian, Keuskupan Jayapura, Catatan Perkembangan Terkini di Papua: Otonomi Khusus, proses dan hasil akhimya [Social-Political note on recent developments in Papua: the special autonomy process and final results] (Jayapura: Sekretariat Keadilan dan Perdamaian, Keuskupan Jayapura, 2001).

${ }^{51}$ Muridan S. Widodo, "Negotiating the Past and Looking to the Future," Inside Indonesia 98 (OctoberDecember, 2009), at http: / / www:inside indonesia.org/weekly-articles/ negotiating-the-past-and-lookingto-the-future, accessed February 10, 2013.
} 
was abandoned, the two years leading up to the 1962 New York Agreement. To be fully effective, reconsideration needs to take place not only in Jakarta and Papua, but also in Washington, DC, where self-determination evaporated in the interests of US Cold War realpolitik. 